
端培食

\title{
化村美江・中野美智子.三浦博史・杉井通泰 大・菜)
}

（長崎

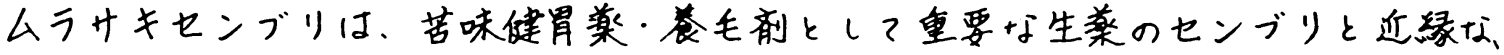
リンドウ科の2年生草本である。強苦味成分の amarogentin 6 amaroswerin は含ん でいないが、主苦味成分の swertiamarinを含有しており、センブりと比較して植物 体が大きく栽培も容易であることから、センブリとムラサキセンブリの体細胞椎㮔 に期待がもたれる。今回は、その基磼研究としてのムラサキセンブリの芽ばえか らのカルス峰導、カルスからの植物体の再分化についマ检討した。また根端培善 にも成功したので、これらについて報告する。

\section{(方法飞結果)}

カルス镍首。長崎县野母崎半岛で採集したムラサキセンブリの種子より発芽さ

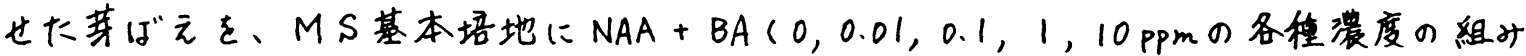

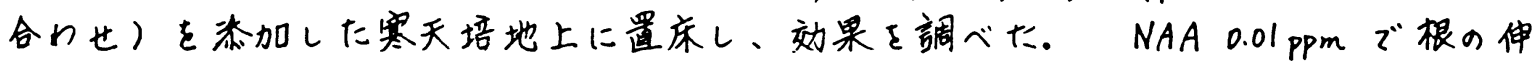
長が、BA 0.1〜10 ppm で菜の生長がみうれた。カルス化はBA漫度に関保けく、

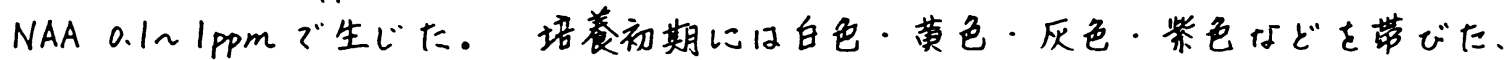
メまざまなカルス塊が得られた。暗所に比較して、明所の方がカルスの生長は著 しく良好であった。

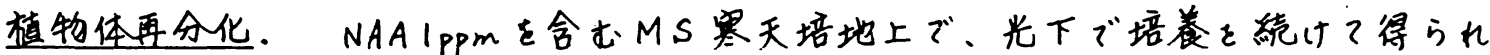

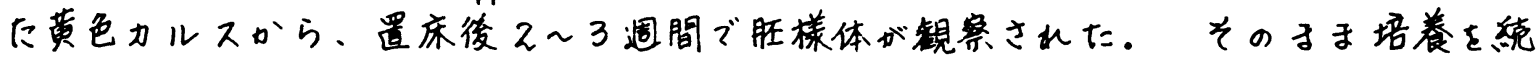
けると3〜4週間㣞には、カルス上に多数の緑色のスポットが网眼で钼察されるよ クに+より、5〜6週間後には根と双菜をもつた植物体が得られた。これをホルモ ンを合于汇心基本培地に移し10〜12週間培卷し、充分成充させたものを土に移植し に。2のえ法によリムラサキセンブリの大量增随が可能であろ。この再分化能 は少くとも64月以上雉持されることがわかった。NAA溃度を下げたり、サイト

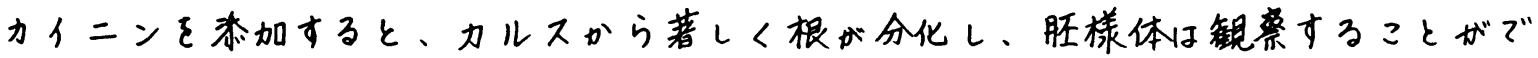
る场かった。

根端培养。カルスより再分化した不定根、およで芽ばえから分離した根端より

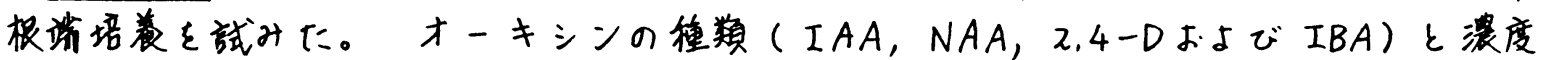
$\left(0,10^{-4}, 10^{-3}, 10^{-2} \mathrm{ppm}\right)$ ，培地の種類（MS，B5，White太よび夜体，寒天培地），

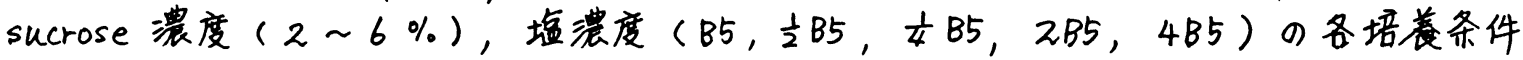
を険討した。その结果、オーキシンの種類としては、NAAとIBAが2、4一DやIAA

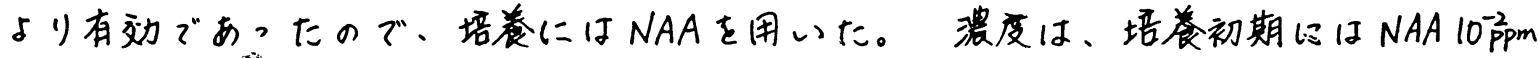
弚の後 NAA $10^{-3} \mathrm{ppm}$ で最も生長が良いつた。培地の種類では、MSでは太心根 が、B5・Whiteでは细い根の生長がみうイたが、伸長はB5が级れていた。寒天培

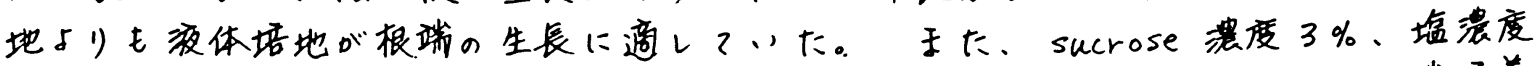
道B5が生長に通していることがわかった。うのようにして增殖率の良い根碳培莨 法を硬立した。 